\title{
Regionale ressurssentre om vold, traumatisk stress og selvmordsforebygging (RVTS)
}

\author{
Ved Henning Herrestad og Kirsti Amundsen
}

\section{Bakgrunn}

I forbindelse med at Norge fikk en nasjonal handlingsplan mot selvmord midt på 1990-tallet, ble det opprettet ett nasjonalt senter for selvmordsforskning og -forebygging ved Universitetet i Oslo, og tre regionale sentre for selvmordsforebygging i Troms $\varnothing$, Trondheim og Bergen. Det ble på denne tiden bygget opp flere slike sentre med spesialkompetanse på ulike problemområder, og det daværende Sosial- og helsedirektoratet hadde ambisjon om å samle dem i større enheter. Flere kompetansemiljøer innen vold og traumatisk stress, samt flyktninge- og migrasjonsproblematikk ble samlet til Nasjonalt kunnskapssenter om vold og traumatisk stress (NKVTS) i 2004.

Nasjonalt senter for selvmordsforskning og -forebygging forble et selvstendig nasjonalt senter på sitt område. På regionalt nivå er de nevnte problemområdene samlet i fem regionale ressurssentre om vold, traumatisk stress og selvmordsforebygging (RVTS) og plassert i henholdsvis Troms $\varnothing$, Trondheim, Bergen, Oslo og Kristiansand.

Målsettingen til RVTS er å bidra til å redusere vansker for barn og voksne som utsettes for vold, seksuelle overgrep og traumatisk stress, eller som er selvmordsnære. Dette gjør de gjennom å samarbeide med hjelperne. Formålet med sentrene er altså å bidra til å styrke den regionale kompetansen i forhold til arbeidet med vold og seksuelle overgrep, flyktningehelse og tvungen migrasjon, og selvmordsforebygging. Kompetansen skal styrkes gjennom direkte samarbeid med praksisfeltet, veiledning, seminarer/undervisning, rådgivning og fagutviklingsprosjekter.

\section{Egne fagteam for \\ selvmordsforebygging}

Hvert RVTS er organisert i ulike fagteam for ulike problemområder, og hvert RVTS har et eget fagteam for selvmordsforebyggende arbeid. Fagteamet har som hovedmålsetting å redusere antall selvmord og selvmordsfors $\varnothing \mathrm{k}$ i sin region, først og fremst gjennom kompetansehevende tiltak til ulike virksomheter og aktører hvor det er viktig å utvikle gode forebyggingsstrategier og tiltak. Det er et mål å bidra til god behandling og oppfølging av mennesker i selvmordskrise og etterlatte ved selvmord. En sentral del av teamenes virksomhet er nettverksbygging og koordinering av oppgaver innenfor og mellom ulike institusjoner, profesjoner og frivillige organisasjoner. RVTSene vektlegger $\phi \mathrm{kt}$ samarbeid mellom fagteamene for å oppnå sentrenes mandat. VIVAT er et nasjonalt program med målsetting om å spre kompetanse om førstehjelp ved selvmordsfare. VIVAT er nå forankret ved RVTS-Nord, og har regionale koordinatorstillinger ved hver av RVTSene. Alle RVTSene har derved en rolle i spredningen av kurset Førstehjelp ved selvmordsfare.

Et annet felles kompetansehevende satsingsområde er arbeidet med å implementere Nasjonale retningslinjer for forebygging av selvmord i psykisk helsevern. RVTSene samarbeider med det nasjonale senteret om å arrangere kurslederkurs for ansatte ved helseforetak, som skal drive internopplæring om selvmordsforebygging i klinikkene.

Et sentralt punkt i den nasjonale handlingsplanen var å etablere behandlingskjeder for personer som ble innlagt i somatisk sykehus etter et selvmordsfors $\varnothing \mathrm{k}$. For å sikre at disse pasientene blir fulgt opp på en forsvarlig måte etter utskrivning skal RVTSene ha en rolle som rådgivere for helseforetakene. Denne funksjonen er sterkest utviklet ved RVTS- $\varnothing_{\text {st }}$ som har etablert et nettverk av spesialrådgivere ved hvert av de 8 helseforetak/ sykehus i regionen.

I tillegg til arbeid rettet mot helsevesenet har alle RVTSene vært engasjert i å st $\varnothing$ tte arbeidet for etterlatte ved selvmord som drives av LEVE - Landsforeningen for etterlatte ved selvmord. RVTSene st $\varnothing$ tter også LEVEs fylkeslag i gjennomføringen av den årlige Verdensdagen for selvmordsforebygging. RVTSene har også tatt initativ til utarbeidelsen av et informasjonshefte til etterlatte ved selvmord som vil bli distribuert gjennom begravelsesbyråene og via Internett.

I tillegg er de ulike teamene engasjert i egne regionale prosjekter. For eksempel har man ved RVTS-Nord startet et arbeid i samarbeid med kommunene og deres psykososiale team for å kartlegge eksisterende og eventuelt bedre rutinene ved oppfølging av etterlatte ved selvmord. RVTS-Nord har også arbeidet med å evaluere effekten av sikringen mot hopp fra Troms $\varnothing$ brua i en toårsperiode etter at sikring ble påmontert. Arbeidet er ferdig og rapporten foreligger, men de vil i samarbeid med

politi og vegmyndigheter fortsette kartleggingen over en lengre periode.

Ved RVTS-Vest har de samarbeidet med lokale organisasjoner om å utvikle helgekurs for etterlatte ved selvmord. De har også kartlagt hvilken oppfølging av etterlatte som gis av den kommunale helsetjenesten RVTS vest i bydelene $\mathrm{i}$ Bergen. Målet er å sikre en bedre oppfølging.

RVTS-Midt vil i

2009 være lokal arrang $\varnothing \mathrm{r}$ for Nasjonal konferanse om selvmordsforebygging $\mathrm{i}$ Trondheim 7.-8. mai.

\section{Kontaktinformasjon:}

\section{Se også www.rvts.no}

Selvmordsforebygging - RVTS Nord

Teamet er tilknyttet Universitetssykehuset Nord-Norge.

Adresse: Fiolveien 15, Troms $\varnothing$.

Tlf. 77627380 / E-post: RVTS@unn.no

Selvmordsforebygging - RVTS Midt

Teamet er tilknyttet St. Olavs hospital. Adresse: Schwachsgt.1, 7030 Trondheim. Tlf. 73861230 / E-post: rvts@stolav.no

Selvmordsforebygging - RVTS Vest

Teamet er tilknyttet Helse Bergen HF og Haukeland universitetssykehus.

Adresse: Ulriksdal Helsepark, Ulriksdal 2, 5009 Bergen. Tlf. 55976696

E-post: rvts@helse-bergen.no

Selvmordsforebygging - RVTS Øst

Teamet er tilknyttet Aker universitetssykehus. Postadresse: Trondheimsvn. 235, 0514 Oslo.

Tlf. 22029007

E-post: rvts@aus.no

Selvmordsforebygging - RVTS Sør RVTS-S $\varnothing$ r er organisert som samarbeidsprosjekt mellom BUF-etat og Helse S $\varnothing$ - $\varnothing$ st RHF. Det holder til på Sørlandet sykehus i Kristiansand.

Adresse: Bygg 21, Serviceboks 416, 4604 Kristiansand. Tlf. 92870256

E-post: anne-lill.haddeland@bufetat.no 